\title{
Pengaruh Ekstrak Etanol Daun Kelor (Moringa oleifera) pada Ekspresi Insulin dan Insulitis Tikus Diabetes Melitus
}

\author{
Ratna Sulistyorini, ${ }^{1}$ Sarjadi, ${ }^{2}$ Andrew Johan, ${ }^{3}$ Kis Djamiatun ${ }^{4}$ \\ ${ }^{1}$ Fakultas Kedokteran Gigi, Universitas Muhammadiyah Semarang, ${ }^{2}$ Bagian Patologi Anatomi Fakultas \\ Kedokteran Universitas Diponegoro, ${ }^{3}$ Bagian Biokimia Fakultas Kedokteran Universitas Diponegoro, ${ }^{4}$ Magister \\ Ilmu Biomedik Fakultas Kedokteran Universitas Diponegoro
}

\begin{abstract}
Abstrak
Kandungan quercetin pada Moringa oleifera secara ilmiah memiliki potensi sebagai antioksidan dan antiinflamasi dengan menghambat aktivitas NF- B, serta triterpenoid menstimulasi regenerasi sel $\beta$ pankreas dan meningkatkan sekresi insulin. Penelitian ini bertujuan melihat pengaruh pemberian ekstrak etanol daun Moringa oleifera terhadap insulitis dan ekspresi insulin pankreas tikus Sprague-Dawley jantan. Penelitian dilakukan di laboratorium Unit Pangan dan Gizi, Pusat Antar Universitas Universitas Gadjah Mada serta Laboratorium Histologi dan Biologi Sel Fakultas Kedokteran Universitas Gadjah Mada, periode Mei-Juli 2013. Penelitian ini menggunakan desain randomized post test only controlled group. Hewan coba sebanyak 24 ekor tikus, diperiksa kadar gula darahnya pada hari ketiga setelah induksi streptozotosin, untuk melihat tikus sudah dalam keadaan hiperglikemik. Tikus kemudian dibagi dalam tiga kelompok: satu kelompok kontrol dan dua kelompok perlakuan yang diberi ekstrak etanol daun Moringa oleifera dosis 250 dan $500 \mathrm{mg} / \mathrm{kg} /$ hari selama 21 hari. Gambaran histopatologik dinilai derajat insulitis pada pulau Langerhans dan dinilai ekspresi insulin dengan skor Allred. Uji statistik yang digunakan adalah Kruskal Wallis dilanjutkan Mann-Whitney dengan taraf kemaknaan $\mathrm{p}<0,05$ karena data tidak berdistribusi normal. Derajat insulitis dan ekspresi insulin pankreas tikus pada kedua kelompok perlakuan menunjukkan perbedaan bermakna dibanding dengan kelompok kontrol $(p<0,005)$. Pada penelitian ini dapat disimpulkan bahwa ekstrak etanol daun Moringa oleifera dosis 250 dan $500 \mathrm{mg} / \mathrm{kg}$ menyebabkan ekspresi insulin lebih tinggi dan derajat insulitis lebih rendah dibanding dengan kelompok kontrol. [MKB. 2015;47(2):69-76]
\end{abstract}

Kata kunci: Ekspresi insulin, insulitis, Moringa oleifera, streptozotosin

\section{Effect of Ethanol Extract of Moringa oleifera Leaves on Insulin Expression and Insulitis in Diabetes Mellitus Rats}

\begin{abstract}
Quercetin content in Moringa oleifera has scientific potential antioxidant and anti-inflammation effects by inhibiting the activity of NF-kB. In addition, triterpenoids stimulate pancreatic $\beta$ cell regeneration and increases insulin secretion. This study aimed to discover the effect of Moringa oleifera extract on insulitis and insulin expression in pancreas of Sprague-Dawley male rats. The study was performed at the laboratory of Food and Nutrition Unit of The Inter University Center of Gadjah Mada University and the laboratory of Histology and Cell Biology Faculty of Medicine Gadjah Mada University during May-July 2013. This was a randomized post test only controlled group study. Twenty four rats were included. Blood glucose test was performed on the third day after streptozotocin induction to ensure that all rats were in hyperglycemic condition. The rats were then divided into three groups: one control group and two treatment groups receiving Moringa oleifera ethanolic leaves extract for 21 days in doses of 250 and $500 \mathrm{mg} / \mathrm{kg} /$ day, respectively. Histopathological analysis of pancreas were performed by evaluating insulitis based on the infiltration of mononuclear inflammatory cells to the Langerhans islets. Insulin expression was evaluated using Allred score. Statistical analysis used was Kruskal-Wallis test, followed by Mann-Whitney with a level of significance of $p<0.05$. The insulitis degree and insulin expression of the two treatment groups were significantly different compared to the control group $(\mathrm{p}<0.005)$. It can be concluded that Moringa oleifera ethanolic leaf extract doses of 250 and $500 \mathrm{mg} / \mathrm{kg} / \mathrm{day}$ cause higher insulin expression and lower insulitis degree than in the control group. [MKB. 2015;47(2):69-76]
\end{abstract}

Key words: Insulin expression, insulitis, Moringa oleifera, streptozotocin

Korespondensi: Ratna Sulistyorini, Fakultas Kedokteran Gigi Universitas Muhammadiyah Semarang, Jalan Kedungmundu Raya No. 22 Semarang, Telepon: 024-672497, mobile 081575813939, e-mail: ratnasulistyorini@yahoo.co.id 


\section{Pendahuluan}

Prevalensi diabetes melitus di dunia meningkat dengan cepat. Prevalensi diabetes melitus pada orang dewasa (20-79 tahun) adalah 6,4\% atau 285 juta pada tahun 2010 dan diperkirakan akan meningkat $7,7 \%$ atau 439 juta pada tahun 2030. ${ }^{1}$ Kementerian Kesehatan RI menilai bahwa diabetes melitus merupakan masalah kesehatan masyarakat. Secara epidemiologis, diperkirakan bahwa pada tahun 2030 prevalensi diabetes melitus (DM) di Indonesia mencapai 21,3 juta orang. ${ }^{2}$

Diabetes melitus tipe 1 (T1DM) merupakan suatu penyakit autoimun kronik yang memiliki komponen radang yang kuat. Radang adalah suatu respons biologis yang dipicu oleh infeksi, cedera jaringan, stres jaringan, atau malfungsi. Pada T1DM, radang islet pankreas (insulitis) memberi kontribusi hilangnya secara progresif sel beta yang memproduksi insulin. Penelitian terakhir menunjukkan bahwa kekebalan bawaan dan mediator radang mempunyai peranan yang lebih luas pada T1DM daripada yang diduga semula, yaitu memberi kontribusi pada induksi dan juga penguatan reaksi imun terhadap sel beta dan pada tahap akhir, menstabilkan dan mempertahankan insulitis. Radang mungkin memberi kontribusi pada destruksi sel beta, supresi yang berkepanjangan pada fungsi sel beta dan selanjutnya apoptosis, serta inhibisi atau stimulasi regenerasi sel beta dan resistensi insulin. $^{3}$

Streptozotosin (STZ) sebagai bahan kimia toksik yang banyak dipakai dalam penelitian hewan coba diabetes melitus akan menginduksi kerusakan sel $\beta$ pankreas melalui alkilasi DNA dengan pembentukan $\mathrm{H}_{2} \mathrm{O}_{2}$ dan reaksi inflamasi. STZ menembus sel $\beta^{2}$ Langerhans melalui afinitas rendah pada transporter glukosa GLUT 2 di membran plasma. Sifat alkilasi ini menyebabkan destruksi DNA sel $\beta$ pankreas yang selanjutnya menginduksi aktivasi poly ADP ribose polymerase (PARP). Lebih lanjut, PARP mengakibatkan deplesi NAD seluler dan ATP sehingga terjadi deplesi simpanan energi sel dan akhirnya sel beta akan mengalami nekrosis. STZ merupakan donor nitric oxide (NO) yang memiliki kontribusi terhadap kerusakan sel tersebut melalui peningkatan aktivitas guanil siklase dan pembentukan cGMP. NO dihasilkan sewaktu STZ mengalami metabolisme dalam sel. Selain itu, STZ juga mampu membangkitkan oksigen reaktif yang mempunyai peran tinggi dalam kerusakan sel $\beta$ pankreas. ${ }^{4,5}$

Tanaman Moringa oleifera yaitu berasal dari selatan kaki gunung Himalaya di utara barat India. Daun Moringa oleifera ini memiliki komposisi nutrisi kimia, asam amino, asam lemak, beta karoten, mineral, dan vitamin E. ${ }^{6}$ Tanaman Moringa oleifera digunakan untuk mengatasi masalah nutrisi, khususnya pada bayi dan ibu menyusui. Daunnya mengandung asam amino esensial, termasuk asam amino yang mengandung belerang dengan kadar yang lebih tinggi daripada yang direkomendasikan oleh Food and Agriculture Organization (FAO). ${ }^{7}$ Asam amino yang terkandung dalam Moringa oleifera adalah lysine, leucine, isoleucine, methionine, cysteine, phenylalanine, tyrosine, valine, histidine, threonine, serine, glutamic acid, aspartic acid, proline, glycine, alanine, arginine, HO-proline, dan tryptophan. ${ }^{6}$

Penelitian fitokimiawi terhadap tanaman Moringa oleifera ini mengungkapkan terdapat polifenol besar misalnya quercetin glucoside, rutin, kaempferol glycoside, dan chlorogenic acid di dalam tepung Moringa oleifera melalui analisis HPLC. ${ }^{8}$ Ekstraksi daun Moringa oleifera dengan metode maserasi dalam larutan etanol 70\%, mengungkapkan bahwa terdapat flavonoids, tannin, anthraquinone, cardiac glycosides alkaloids, triterpenoids, saponins, dan reducing sugars. Penelitian Tende dkk. ${ }^{9}$ menunjukkan bahwa flavonoid mempunyai efek hipoglikemik, meskipun efek hipoglikemik terpenoid tampak terlibat dalam menstimulasi sel $\beta$ pankreas dan selanjutnya meningkatkan sekresi insulin. Penurunan kadar glukosa darah setelah 1-7 jam pemberian ekstrak etanol Moringa oleifera dosis 250 dan $500 \mathrm{mg} / \mathrm{kgBB}$ terlihat pada kelompok tikus diabetes yang diinduksi STZ dibanding dengan kelompok kontrol, tetapi dosis efektif hipoglikemik diperlihatkan pada dosis $500 \mathrm{mg} /$ kgBB. ${ }^{9}$ Flavonoid mempunyai aktivitas sebagai antioksidan yang mampu menekan radikal bebas (ROS). Quercetin merupakan salah satu flavonoid yang berkhasiat sebagai antioksidan. Flavonol quercetin ditemukan dengan konsentrasi yang tinggi pada daun Moringa oleifera. Quercetin mempertlihatkan aktivitas sebagai antioksidan dengan menurunkan peroksidasi lipid (MDA) dan meningkatkan aktivitas enzim antioksidan pada tikus diabetes melitus yang diinduksi STZ. ${ }^{10}$ Evaluasi toksisitas oral ekstrak air daun Moringa oleifera dilakukan pada tikus dengan parameter hematologi, biokimia, dan histologi. Pada tes toksisitas akut, ekstrak Moringa oleifera tidak menyebabkan kematian pada hewan, bahkan pada dosis $2.000 \mathrm{mg} / \mathrm{kgBB}$ sehingga relatif aman sebagai nutrisi dan untuk pengobatan. ${ }^{11,12}$

Tujuan penelitian ini adalah membuktikan 
pengaruh pemberian ekstrak etanol daun kelor (Moringa oleifera) 250 dan 500 mg/ $\mathrm{kgBB}$ terhadap ekspresi insulin dan insulitis pankreas tikus Spraque Dawley yang diinduksi streptozotosin.

\section{Metode}

Penelitian ini dilakukan di Laboratorium Unit Pangan dan Gizi Pusat Antar Universitas UGM dan laboratorium Histologi dan Biologi Sel Fakultas Kedokteran Universitas Gadjah Mada, periode Mei-Juli 2013. Penelitian yang dilakukan adalah jenis penelitian eksperimental dengan kelompok perlakuan diberi ekstrak etanol daun Moringa oleifera per oral dengan dosis 250 dan $500 \mathrm{mg} /$ $\mathrm{kgBB} /$ hari. Rancangan penelitian menggunakan rancangan eksperimental randomized post test only controlled group design.

Subjek penelitian adalah 24 ekor tikus dengan kriteria inklusi tikus jantan, strain Sprague Dawley, usia 2-3 bulan, bobot badan 150-250 gram, selama observasi 7 hari sebelum perlakuan kondisi sehat dengan aktivitas dan tingkah laku normal. Kriteria eksklusi tikus selama observasi 7 hari tampak sakit (gerakan tidak aktif). Tikus dibagi dalam 1 kelompok kontrol (12 ekor) serta 2 kelompok perlakuan, yang masing-masing kelompok terdiri atas 6 ekor tikus Sprague Dawley jantan. Pakan standar dan minum tikus, ekstrak etanol daun Moringa oleifera dosis 250 dan $500 \mathrm{mg} / \mathrm{kgBB} / \mathrm{hari}$, STZ $40 \mathrm{mg} / \mathrm{kgBB}$, bahan-bahan penatalaksanaan jaringan untuk sediaan histopatologi, pengecatan rutin jaringan hematoxylin-eosin (HE), dan pembuatan sediaan imunohistokimia.

Penelitian dimulai dengan aklimatisasi hewan uji dalam lingkungan laboratorium selama satu minggu untuk penyesuaian hewan uji dengan lingkungannya. Kemudian, tikus diinduksi STZ dosis $40 \mathrm{mg} / \mathrm{kgBB}$ secara intraperitoneal.

Pemeriksaan kadar glukosa darah untuk menilai keberhasilan induksi STZ dilakukan 1 (satu) kali pada 48 jam setelah induksi STZ dengan mengambil darah intraorbita memakai mikrohematokrit yang selanjutnya kadar glukosa darah diperiksa dengan metode enzimatic colorimetric test "GOD-PAP". Tikus dengan kadar glukosa darah $>132 \mathrm{mg} / \mathrm{dL}$ dimasukkan dalam kelompok kontrol (kelompok hiperglikemik) 12 ekor, kelompok perlakuan 1 (6 ekor), dan kelompok perlakuan 2 (6 ekor). Pada kelompok kontrol, diterminasi 6 ekor untuk dilakukan pemeriksaan ekspresi insulin dan insulitis. Pada kelompok perlakuan, tikus diberikan ekstrak etanol daun Moringa oleifera per oral lewat sonde dengan dosis $250 \mathrm{mg} / \mathrm{kgBB} /$ hari (perlakuan 1) dan $500 \mathrm{mg} / \mathrm{kgBB} /$ hari (perlakuan 2) pada hari ke-3 setelah induksi STZ. Perlakuan dilaksanakan setiap hari selama 21 hari.

Setelah 21 hari, tikus diterminasi dengan cara dibius menggunakan kloroform, kemudian dibedah mempergunakan disecting kit untuk mengambil jaringan pankreas dan dibuatkan sediaan histopatologi, dilanjutkan pengecatan rutin jaringan hematoxylin-eosin (HE) dan imunohistokimia insulin.

Ekspresi insulin itu ternyata dapat dinilai pada jumlah sitoplasma sel $\beta$ pankreas yang terpulas berwarna coklat (proportion score) dan derajat intensitas warnanya (intensity score). Penilaian mempergunakan skor Allred, dilakukan secara manual pada pembesaran 400 kali, pada 10 zona lapangan pandang, minimal 10 pulau Langerhans dengan menjumlahkan proportion score dan intensity score dengan range 0-8. Nilai scoring ditentukan oleh dua pemeriksa.

Insulitis dinilai dari gambaran histologik pankreas, yaitu pada serbukan sel-sel radang mononuklear di sekitar pulau-pulau Langerhans pankreas. Penilaian dengan melihat derajat insulitis pada pulau Langerhans dan di daerah sekitarnya pada pembesaran 400 kali, secara konsisten pada 10 zona lapangan pandang, minimal 10 pulau Langerhans.

Skor Allred dari penilaian ekspresi insulin merupakan data dengan skala ratio. Analisis deskriptif tersebut ditampilkan dalam bentuk nilai maksimun, minimum rata-rata, dan juga simpangan baku. Lalu, dilakukan uji distribusi dengan Saphiro Wilk, memperlihatkan bahwa distribusi data penelitian tidak normal sehingga dipergunakan analisis Kruskal Wallis dan Mann Whitney. Analisis insulitis pankreas ditampilkan dalam bentuk tabel frekuensi dan persentase, lalu dilanjutkan analisis Kruskal Wallis dan Mann Whitney.

Implikasi etik pada hewan coba yaitu berupa pengelolaan binatang coba itu sudah sesuai dengan animal ethics, mempergunakan prinsip 3R (replacement, refinement, reduction) dan telah mendapatkan persetujuan dari Komite Etik Penelitian Kesehatan Fakultas Kedokteran Universitas Diponegoro. Proses pengelolaan binatang coba dalam kandang, pemberian makanan dan minum (ad libitum), sirkulasi dan kelembaban udara dalam ruang kandang, perlakuan saat penelitian, penghilang rasa sakit, serta pengambilan unit analisis penelitian dan 
Tabel 1 Nilai Skor Allred Ekspresi Insulin dalam Nilai Minimum, Nilai Maksimum, Rata-rata dan SD

\begin{tabular}{|c|c|c|c|c|}
\hline Kelompok & Minimum & Maksimum & Rata-rata & SD \\
\hline K1 & 0 & 7 & 4,13 & 1,157 \\
\hline K2 & 3 & 7 & 4,80 & 0,971 \\
\hline P1 & 5 & 8 & 7,58 & 0,591 \\
\hline $\mathrm{P} 2$ & 7 & 8 & 7,85 & 0,360 \\
\hline
\end{tabular}

Keterangan:

K1: Kelompok kontrol (hiperglikemik), 3 hari setelah induksi streptozotosin

K2: Kelompok kontrol (hiperglikemik), 24 hari setelah induksi streptozotosin

P1 Kelompok perlakuan, dosis $250 \mathrm{mg} / \mathrm{kgBB} / \mathrm{hari}$

P2 Kelompok perlakuan, dosis $500 \mathrm{mg} / \mathrm{kgBB} / \mathrm{hari}$

pemusnahan hewan coba.

\section{Hasil}

Kadar glukosa darah rata-rata pada 48 jam setelah induksi STZ pada semua kelompok adalah $189,92 \pm 5,27 \mathrm{mg} / \mathrm{dL}$, menunjukkan tikus sudah dalam keadaan hiperglikemik (kadar glukosa darah $>132 \mathrm{mg} / \mathrm{dL}$ ).

Tabel 1 menunjukkan nilai skor Allred ratarata tertinggi pada pada kelompok perlakuan 2 yang diberi ekstrak etanol daun Moringa oleifera dosis $500 \mathrm{mg} / \mathrm{kgBB} / \mathrm{hari}$, sedangkan rata-rata terendah pada kelompok $\mathrm{K} 1$, yaitu kelompok kontrol (hiperglikemik) yang tidak diberikan perlakuan. Hasil uji beda ekspresi insulin memperlihatkan perbedaan bermakna antara kelompok penelitian yaitu $\mathrm{p}<0,005$. Gambaran histopatologik skor Allred dengan pengecatan insulin, kelompok tikus dengan pemberian ekstrak etanol daun Moringa oleifera menunjukkan pewarnaan secara bermakna lebih kuat dibanding dengan kelompok hiperglikemik (Gambar 1).

Tabel 2 memperlihatkan persentase tertinggi ialah derajat insulitis 2 (insulitis sedang), yaitu $70,8 \%$ dan frekuensi terbanyak pada kelompok K2 (kelompok hiperglikemik), yaitu 54 sampel. Derajat insulitis 3 (insulitis berat) hanya ditemukan padakelompokK2 dan derajatinsulitis 4 (end stage islet) tidak ditemukan pada semua kelompok. Hasil uji beda insulitis menunjukkan perbedaan bermakna antara kelompok kontrol

Tabel 2 Derajat Insulitis dalam Frekuensi dan Persentase

\begin{tabular}{lcccccc}
\hline \multirow{2}{*}{ Kelompok } & \multicolumn{7}{c}{ Derajat insulitis } \\
\cline { 2 - 7 } & 0 & 1 & 2 & 3 & 4 & $\Sigma$ sampel \\
\hline K1 & 4 & 18 & 38 & 0 & 0 & 60 \\
K2 & 0 & 0 & 54 & 6 & 0 & 60 \\
P1 & 3 & 18 & 39 & 0 & 0 & 60 \\
P2 & 4 & 17 & 39 & 0 & 0 & 60 \\
Frekuensi & 11 & 53 & 170 & 6 & 0 & 240 \\
Persentase (\%) & 4,6 & 22,1 & 70,8 & 2,5 & 0 & 100 \\
\hline
\end{tabular}

Keterangan:

K1: Kelompok kontrol (hiperglikemik), 3 hari setelah induksi streptozotosin

K2: Kelompok kontrol (hiperglikemik), 24 hari setelah induksi streptozotosin

P1: Kelompok perlakuan, dosis $250 \mathrm{mg} / \mathrm{kgBB} /$ hari

P2: Kelompok perlakuan, dosis $500 \mathrm{mg} / \mathrm{kgBB} / \mathrm{hari}$

Derajat insulitis:

0: normal

1: insulitis ringan

2: insulitis sedang

3: insulitis berat

4: end stage islet 

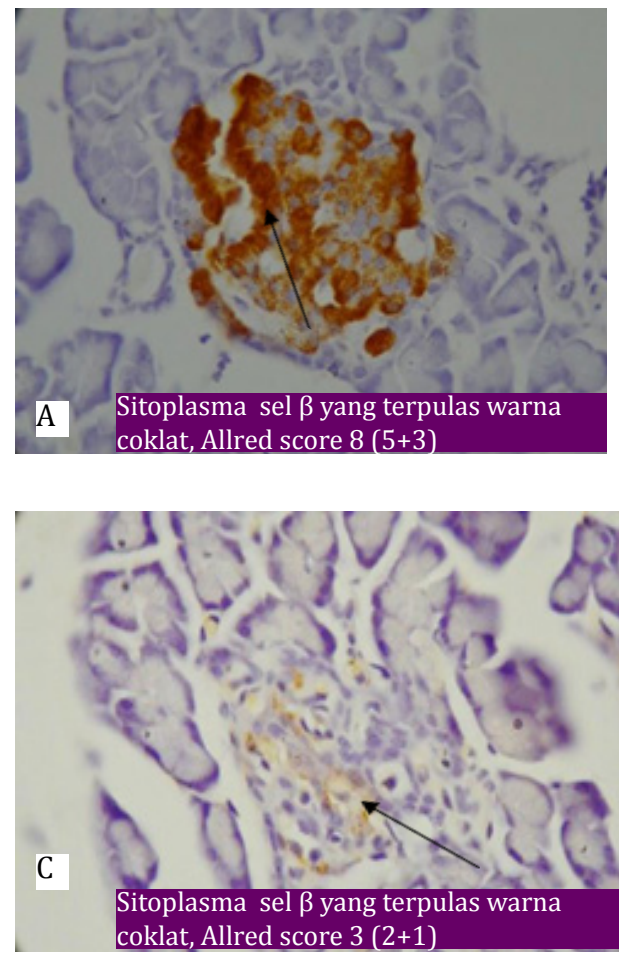
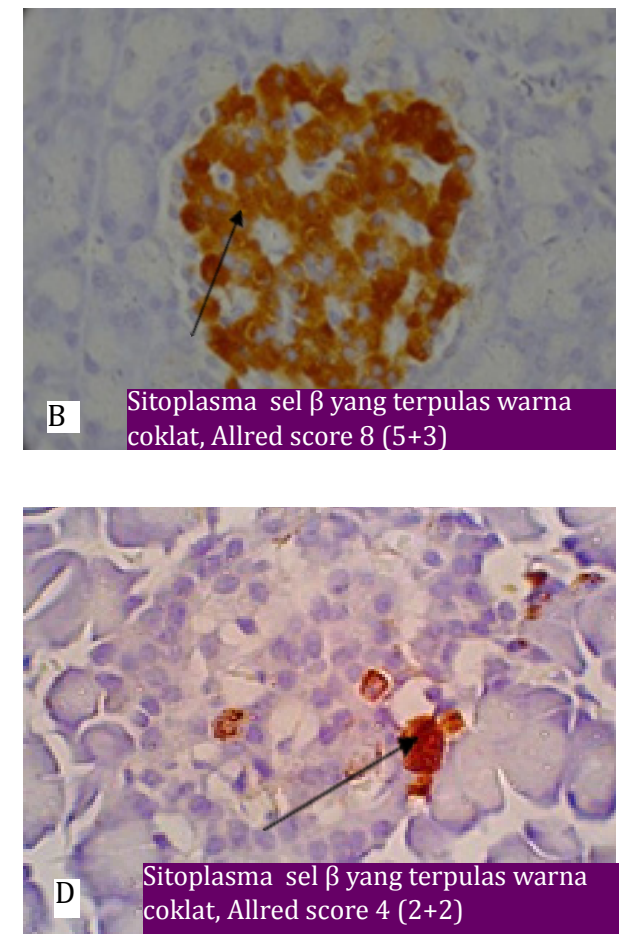

Gambar 1 Gambaran Histopatologi Skor Allred dengan Pengecatan Insulin, Pembesaran 400x A. INS positif pada kelompok perlakuan 1 skor Allred $8(5+3)$. B. INS positif pada kelompok perlakuan 2 skor Allred $8(5+3)$. C. INS positif pada kelompok hiperglikemik 3 skor Allred $3(2+1)$. D. INS positif pada kelompok hiperglikemik 24 skor Allred $4(2+2)$
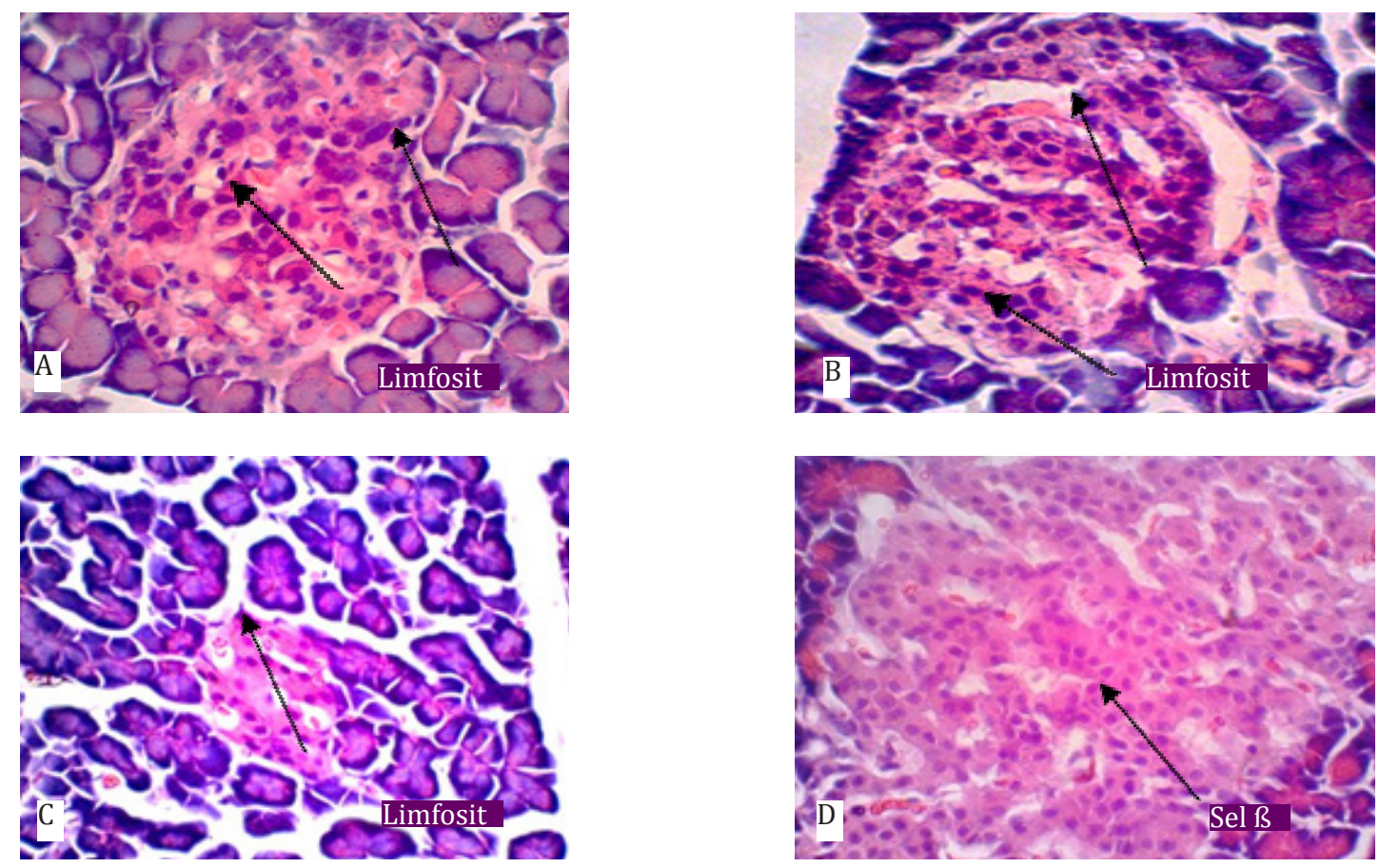

Gambar 2 Gambaran Histopatologik Insulitis dengan Pengecatan HE, Pembesaran 400x

A. Insulitis sedang, sebukan sel-sel radang mononuklear (limfosit) menginfiltrasi sebagian kecil $(<50 \%)$ pulau Langerhans B. Insulitis berat, serbukan sel-sel radang mononuklear (limfosit) menginfiltrasi sebagian besar ( $>50 \%$ ) pulau Langerhans C. Insulitis ringan, sebukan sel-sel mononuklear (limfosit) di sekitar pulau Langerhans (periinsulitis) D. Pulau Langerhans 
dan kelompok perlakuan $(\mathrm{p}<0,005)$, sedangkan antara kelompok perlakuan 1 (P1) dan kelompok perlakuan 2 (P2) menunjukkan perbedaan tidak bermakna $(p>0,005)$. Gambaran histopatologik insulitis dengan pengecatan HE menunjukkan bahwa pada insulitis ringan, insulitis sedang, dan insulitis berat, arsitektur pulau Langerhans masih tampak jelas dan terlihat serbukan sel-sel radang mononuklear (limfosit) (Gambar 2).

\section{Pembahasan}

Kenaikan kadar glukosa darah terjadi pada semua kelompok tikus pada 48 jam setelah induksi STZ. Setelah pemberian STZ, efek diabetogenik diinisiasi oleh reactive oxygen species (ROS) melalui efek toksik langsung pada GLUT ${ }^{13}$ Ekstrak etanol daun Moringa oleifera terbukti mempunyai efek menurunkan hiperglikemik pada tikus diabetes melitus yang diinduksi STZ kemungkinan karena stimulasi sel $\beta$ dan atau karena aktivitasnya yang mirip insulin. Efek hipoglikemik daun Moringa oleifera disebabkan terdapat flavonoid dan metabolit sekunder lainnya termasuk arginin dan asam glutamat, meskipun terpenoid tampak terlibat di dalam menstimulasi sel $\beta$ pankreas dan selanjutnya meningkatkan sekresi insulin. ${ }^{9}$ Pada penelitian lain, ekstrak air daun Moringa oleifera dapat menurunkan dan menormalisir kadar glukosa darah yang tinggi dan memperbaiki toleransi glukosa, mungkin dapat diduga bahwa ekstrak air daun Moringa oleifera mempunyai efek langsung yaitu meningkatkan penggunaan glukosa oleh jaringan dengan menginhibisi glukoneogenesis hepatik atau absorpsi glukosa ke dalam otot atau jaringan adiposa. ${ }^{14}$

Penelitian ini merupakan penelitian pertama yang dapat membuktikan bahwa pemberian perlakuan ekstrak etanol daun Moringa oleifera meningkatkan ekspresi insulin pankreas pada tikus yang diinduksi STZ. Penelitian sebelumnya mempergunakan ekstrak metanol polong Moringa oleifera membuktikan lebih tingginya kadar insulin dan pemulihan kerusakan histoarsitektural sel $\beta$ pankreas tikus Wistar yang diinduksi STZ yang diberi perlakuan ekstrak tersebut dibanding dengan kelompok yang tanpa perlakuan. Pada penelitian tersebut ditemukan bahwa peningkatan peroksidasi lipid yang secara bersamaan disertai pengurangan superoxide dismutase (SOD), catalase (CAT), dan glutathione (GSH) pada pankreas tikus diabetik. Peroksidasi lipid adalah suatu indeks produksi malondyaldehide (MDA) dan pemberian ekstrak metanol polong Moringa oleifera terbukti dapat meningkatkan kadar antioksidan pada jaringan pankreas. Ekstrak metanol polong Moringa oleifera juga terbukti mengandung quercetin dan kaempherol yang diperkirakan meningkatkan induksi sekresi insulin oleh glukosa pada sel $\beta$ pankreas yang masih berfungsi. ${ }^{15}$ Penelitian dengan ekstrak metanol polong Moringa oleifera tersebut tidak menindaklanjuti pemeriksaan ekspresi insulin pada sel $\beta$ pankreas dan insulitis pada pulau Langerhans.

Pemberian ekstrak etanol daun Moringa oleifera ternyata dapat memengaruhi perbaikan kerusakan pulau Langerhans pankreas akibat induksi STZ dengan menghambat proses radang (insulitis) karena memiliki kemampuan sebagai anti-inflamasi. Serbukan infiltrat pada pankreas lebih sedikit pada kelompok tikus yang diberi perlakuan ekstrak etanol daun Moringa oleifera dibanding dengan kelompok tanpa perlakuan. Mekanisme sebagai anti-inflamasi yang dapat mengakibatkan penurunan kadar TNF- $\alpha$ yaitu melalui hambatan terhadap nuclear factor kappa $B$ (NF-kB). NF-kB menjadi aktif karena stimulus agen-agen ROS yang menyebabkan disfungsi endotel, pathogen exposure, kerusakan DNA, dan stres fisik. NF-KB berfungsi dalam mengontrol ekspresi gen yang mengkode sitokin proinflamasi dan kemokin seperti TNF- $\alpha$, IL-1 $\beta$, IL-6, dan protein lainnya. ${ }^{16}$ Senyawa-senyawa aktif dalam ekstrak daun Moringa oleifera mempunyai jalur yang dapat menghambat proses inflamasi pada pulau Langerhans, yaitu sebagai inhibitor iNOS, menghambat produksi NO dan inhibitor aktivasi NF-kB ${ }^{17}$ yang berperan penting sebagai regulator utama reaksi imunologi dan inflamasi pada induksi STZ. ${ }^{13}$ Pada penelitian ini, hambatan pada NF-kB akan melemahkan respons inflamasi dengan menghambat proses radang pulau Langerhans (insulitis). ${ }^{17}$

Kandungan daun Moringa oleifera yang memiliki peran penting dalam aksi antioksidan yaitu flavonoid. Komponen bioaktif fenol utama daun Moringa oleifera yang merupakan golongan flavonoid adalah quercetin yang mempunyai kemampuan untuk mengikat atom atau sebagai scavenging bagi radikal bebas sehingga tidak terbentuk ROS berlebihan. ${ }^{10}$ Aktivitas yang kuat sebagai scavenger yang mampu meningkatkan aktivitas superoxide dismutase (SOD) dan juga catalase (CAT). SOD adalah garis pertahanan pertama terhadap ROS yang mengonversi $\mathrm{H}_{2} \mathrm{O}_{2}$ selanjutnya catalase melakukan detoksifikasi $\mathrm{H}_{2} \mathrm{O}_{2}$ menjadi molekul oksigen dan air. ${ }^{16}$ Potensi sebagai scavenging hidrogen peroksida dari ekstrak etanol Moringa oleifera lebih tinggi 
dibandingkan dengan asam askorbat. Keadaan ini memperlihatkan bahwa ekstrak mungkin dapat melindungi sel dari kerusakan oksidatif, khususnya kerusakan DNA oleh karena paparan hidrogen peroksida. ${ }^{18}$

Senyawa aktif pada daun Moringa oleifera yang sudah terbukti mempunyai efek hipoglikemik pada tikus yang diinduksi streptozotosin adalah flavonoid (quercetin dan kaempherol) serta triterpenoid.Flavonoidyaitu merupakan senyawa yang mampu meregenerasi sel $\beta$ pankreas dan sesuai dengan penelitian Adewole dkk. ${ }^{10}$ bahwa tikus diabetes melitus yang diinduksi STZ dan diterapi quercetin tidak ditemukan infiltrasi sel radang dan islet terlihat mengalami peningkatan dalam intensitas granulasi. Quercetin mampu menstimulasi sel-sel progenitor pada saluran pankreas untuk berdiferensiasi membentuk sel pulau Langerhans baru atau sel endokrin pada tikus diabetes melitus ${ }^{17}$ sehingga pemberian ekstrak daun Moringa oleifera yang mempunyai kandungan di berbagai vitamin, mineral, dan asam amino esensial yang akan berguna dalam regenerasi sel. ${ }^{7,19}$ Senyawa aktif masing-masing dalam ekstrak daun Moringa oleifera tersebut mempunyai mekanisme yang berbeda, tetapi secara sendiri-sendiri ataupun bersama-sama mempunyai efek positif di dalam memperbaiki kerusakan sel $\beta$ pankreas akibat induksi STZ.

Hasil uji beda ekspresi insulin terdapat perbedaan bermakna antara kelompokpenelitian $(\mathrm{p}<0,005)$. Keadaan ini menunjukkan pemberian ekstrak etanol daun Moringa oleifera dosis 250 dan $500 \mathrm{mg} / \mathrm{kgBB}$ selama 21 hari mampu memperbaiki kerusakan sel $\beta$ pankreas akibat induksi streptozotosin. Hasil uji beda insulitis terdapat perbedaan bermakna antara kelompok hiperglikemik dan juga kelompok perlakuan $(\mathrm{p}<0,005)$, memperlihatkan pemberian ekstrak etanol daun Moringa oleifera dosis 250 dan 500 $\mathrm{mg} / \mathrm{kgBB}$ selama 21 hari mampu menurunkan insulitis pulau Langerhans pankreas akibat induksi streptozotosin. Namun, efek ekstrak etanol daun Moringa oleifera ini belum mampu mengembalikan pulau Langerhans kembali pada keadaan normal.

Simpulan, bahwa kelompok hiperglikemik dengan perlakuan ekstrak etanol daun Moringa oleifera dosis 250 dan $500 \mathrm{mg} / \mathrm{kgBB}$ memiliki ekspresi insulin rata-rata lebih tinggi dan juga insulitis yang lebih rendah dibanding dengan kelompok hiperglikemik tanpa perlakuan. Untuk perkembangan selanjutnya dan dapat dilakukan pengujian klinis serta keamanan penggunaan dari ekstrak etanol daun Moringa oleifera dalam penggunaannya pada manusia.

\section{Daftar Pustaka}

1. Shaw JE, Sicree RA, Zimmet PZ. Global estimates of the prevalence of diabetes for 2010 and 2030. Diab Res Clin Practice. 2010;87(1):4-14.

2. Kementerian Kesehatan RI. Tahun 2030 Prevalensi diabetes melitus di indonesia mencapai 21,3 juta orang [diunduh 14 Oktober 2012]. Tersedia dari: http://www. depkes.go.id

3. Eizirik DL, Colli ML, Ortis F. The role of inflammation in insulitis and B-cell loss in type 1 diabetes. Nature Rev Endocrinol. 2009;5(4):219-26.

4. Ali S, Rohilla A, Dahiya A, Kushnoor A, Rohilla S. Streptozotocin induced diabetes: Mechanisms of induction. Int J Pharm Res Develop. 2011;4(04):011-5.

5. Akbarzadeh A, Norouzian D, Mehrabi MR, Jamshidi S, Farhangi A, Verdi AA, dkk. Induction of diabetes by streptozotocin in rats. Indian J Clin Biochem. 2007;22(2):60-4.

6. Moyo B, Masika P, Hugo A, Muchenje V. Nutritional characterization of Moringa (Moringa oleifera Lam.) leaves. Afr J Biotech. 2011;10(60):12925-33.

7. Tilong AD. Ternyata kelor penakluk diabetes. Yogjakarta: DIVA Press; 2012.

8. Johnson BC. Clinical perspective on the health effects of moringa oleifera a promising adjunct for balanced nutrition and better health. KOS Health Publications. 2005;1:1-5.

9. Tende JA, Ezekiel I, Dikko AAU, Goji ADT. Effect of ethanolic leaves extract of moringa oleifera on blood glucose levels of streptozotocininduced diabetics and normoglycemic wistar rats. Br J Pharm Toxicol. 2011;2(1):1-4.

10. Adewole SO, Adewole SO, Caxton-Martins EA, Ojewole JA. Protective effect of quercetin on the morphology of pancreatic beta-cells of streptozotocin-treated diabetic rats. Afr J Tradit Complement Altern Med. 2006;4(1): 64-74.

11. Kasolo JN, Bimenya GS, Ojok L, Ochieng J, Ogwal-Okeng JW. Phytochemicals and uses of Moringa oleifera leaves in Ugandan rural communities. J Med Plants Res. 2010;4(9): 753-7.

12. Mbikay M. Therapeutic potential of Moringa oleifera leaves in chronic hyperglycemia and dyslipidemia. Front Pharmacol. 2012;3(24): $1-12$.

13. Lgssiar A, Hassan M, Schott-Ohly P, Ffriesen N, Nicoletti F, Trepicchio WL, dkk. Interleukin-11 inhibits NF-KB and AP-1 
activation islets and prevents diabetes induced with streptozotocin in mice. Exp Biol Med. 2004;229(5):425-36.

14. Jaiswal D, Rai PK, Kumar A, Mehta S, Watal G. Effect of Moringa oleifera lam. leaves aqueous extract therapy on hyperglycemic rats. J Ethnopharmacol. 2009;123(3):392-6.

15. Gupta R, Mathur M, Bajaj VK, Katariya P, Yadav S, Kamal R, dkk. Evaluation of antidiabetic and antioxidant activity of Moringa oleifera in experimental diabetes. J Diab. 2012;4(2):164-71.

16. Ogbunugafor $H$, Igwo-Ezikpe $M$, Igwilo I, Ozumba N, Adenekan S, Ugochukwu $\mathrm{C}$, dkk. In vitro and in vivo evaluation of antioxidant properties of moringa oleifera ethanolic leaves extract and effect on serum lipid indices in rat. Maced J Med Sci. 2012;5(4):397-403.

17. Rifaai RA, El-Tahawy N, Saber EA, Ahmed R. Effect of quercetin on the endocrine pancreas of the experimentally induced diabetes in male albino rats: a histological and immunohistochemical study. J Diab Metab. 2012;3(3):1-11.

18. Ramakhrisna V, Jailkhani R. Evaluation of oxidative stress in insulin dependent diabetes mellitus (IDDM) patients. Diag Pathol. 2007;2(22):1-6.

19. Farooq F, Rai M, Tiwari A, Khan AR, Farooq S. Medicinal properties of Moringa oleifera: an overview of promosing healer. J Med Plants Res. 2012;6(27):4368-74. 